\title{
The Settlement of Law on Regional Cooperation in Biological Natural Resources Management
}

\author{
Luh Putu Sudini \\ Faculty of Law \\ Universitas Warmadewa \\ Denpasar, Bali, Indonesia \\ sudini_putu@yahoo.co.id
}

\begin{abstract}
This article aims to examine and describe the settlement of law concerning regional cooperation in the management of biological natural resources within the scope of the Exclusive Economic Zone. This research is a type of normative legal research conducted by following statute approach and conceptual approach. The results show that the settlement of law on regional cooperation in the management of biological natural resources in the Exclusive Economic Zone is contained in the Law and the Article: ASEAN Ministerial Understanding on Fisheries Cooperation Year 1983; and the 1982 Sea Law Convention, Article 556 paragraph (2); Article 63; Article 64; Article 67 paragraph (3); Article 69; Article 70 paragraph (3); Article 123. The management of natural resources has a strong protection umbrella so that legal maintenance should be realized under such Regional cooperation of ASEAN member countries (Association of Southeast Asian Nations) as one of the efforts undertaken in the Exclusive Economic Zone (EEZ) to utilize biological natural resources. Thus, promising organized management has been put.
\end{abstract}

Keywords-settlement, law; regional cooperation; management of biological natural resource

\section{INTRODUCTION}

The conservation of natural resources and environment (KSDAL) is the responsibility of all human beings on earth because the ecological impacts of various development activities are not limited by the different administrative regions of state government. Conservation efforts, therefore, must become an integral part of development. Development undertaken in any country will be related to the interests of other countries as well as international interests. KSDAL is the joint responsibility of all people on earth, so it is necessary to consider the establishment of institutional networks either regionally, nationally, and internationally. One example is the national park. National park is one form of the conservation area that has had strong enough institutional in various countries. Various forms of international cooperation are recognized as meaningful for the less fortunate countries in handling their own conservation areas. It implements a mechanism for joint costing, through a fair sharing of costs and benefits of conservation area management, both among protected areas and the surrounding community.
At every level of society, there are stakeholders, both at the public and private levels, who are primarily concerned with efforts to improve management and policy settlement [1]. Whereas if there is a reserve of natural oil, natural gas, and coal may seem widespread, growing demand for electricity and mobility around the world threaten to drain them in the near future [2]. In other words, the world is transitioning from an abundant supply position of fossil energy to most of the future supply of limited resources. Conservation can also be viewed from an economic and ecological perspective where economic conservation means trying to allocate natural resources for now, whereas in terms of ecology, conservation is the allocation of natural resources for now and the future.

Study on the natural resources protection has for years been conducted in order to meet a clear application of regulations and policies in their management. A study on the review of current Indonesian laws and policies for an ecosystem approach to fisheries management (EAFM); an assessment to identify gaps, challenges and opportunities for an EAFM; and recommendations for EAFM implementation confirms that a strong co-management structure of the fishery management area (FMA) governance is at the heart of EAFM implementation [3]. In addition, there are a number of studies on science that are more suitable to support effective natural resource management efforts through various approaches, including sustainability science, social-ecological systems, and resilience thinking frameworks and approaches $[4,5,6]$. These approaches combine with the study of sustainability and social and ecological resilience as interrelated aspects of one another; draws a common thread on the importance of linking the role of the social sciences in decision-making over natural resource management. Social science can be an aid in managing natural resources, including biological resources (1) identifying and evaluating social sacrifices in the form of legal and ecological barriers associated with different management options.

A review has been conducted in several national legislations governing the conservation of biological natural resources and ecosystems in Indonesia. The regulations reviewed include (1) the Law and (4) Government Regulations covering Law Number 5 of 1990; Government Regulation No. 18/1994, No. 68/1998, No. 7/1999 and No. 8/1999. For this purpose the ad hoc team was established under the supervision of the National Forestry Council (DKN). 
This regulation provides provisions on permit systems for the utilization of protected areas for recreation, but it has been found that recreational park use for recreational purposes is not well developed due to regulatory weaknesses. They are among the issues and issues identified by the ad hoc team over a six month working period [7].

Studies of the role of natural resource law in bioeconomy and the consideration of the need to develop better ager legislation to be able to meet future challenges are also necessary. It can be done by evaluating the rules governing the use of forests as one form of natural resource perspective bioeconomy. Of course, this action aims to recognize and reduce potential barriers and overcome shortcomings and develop new ways to facilitate the transition to bioeconomy [8]. In order to realize the management of natural resources, the need to be one of the strongest factors that is useful for enhancing integration, adaptability, transparency and public participation in forestry regulations to facilitate transition and sustain biology natural resources.

The management of natural resources formed by the territorial context in which it occurs, as well as the way in which resource management contributes to forming new territories [9]. It can increase knowledge of the process of territorialization in the workplace by identifying different regions within the same geographical area and positioning local stakeholders, understood as local residents, in connection with the territorial interface.

The United Nations Convention on the Law of the Sea (UNCLOS), also called the International Sea Law Convention or the Law of the Sea Treaty, is an international treaty resulting from the United Nations Conference on the Law of the Sea the third (UNCLOS III) which lasted from 1973 to 1982This Sea Law Convention defines the state's rights and responsibilities in the use of oceans in the world and establishes guidelines for the business, environment, and management of marine natural resources. The Convention concluded in 1982, replacing an international agreement on the sea in 1958. UNCLOS came into force in 1994 (International Sea Law Convention: 1982), a year after Guyana became the 60th country to sign the treaty. To date, there have been 158 countries, including the European Union, have joined the convention [10].

Indonesia is also a member of several international and regional conventions or bilateral agreements on biodiversity conservation, including CITES, Ramsar and CBD, which require national legislation for effective implementation at the national level. It is for this purpose that Law Number 5 of 1990 and its implementing regulations have been employed as national legislation for the implementation of CITES. Two implementing regulations that provide wild species preservation and utilization of wild species are Government Regulation No. 7 and Government Regulation No. 8 of 1999 respectively.

Natural resources (commonly referred to as SDA) are anything derived from nature that can be used to meet the needs of human life [11]. It can be classified in them that they include not only biotic components, such as animals, plants, and microorganisms, but as well as abiotic components, such as petroleum, natural gas, various metals, water, and soil.
Natural resources can be distinguished into biological natural resources and non-biological natural resources. Based on Article 5 of Law Number 5 of 1990 and the World Conservation Strategy, the conservation activities of biological natural resources and their ecosystems include: (1) Protection of essential or substantial ecological processes in life-support systems (2) Preservation of the diversity of plant and animal species and their ecosystems; and (3) The sustainable use of biological natural resources and their ecosystems.

Building this, this paper aims to describe the legal arrangements governing cooperation in the management of biological resources in the context of Exclusive Economic Zone

\section{METHOD}

This research is a type of normative legal research [12]. This means that assessment is based on legal rules, legal norms or legal provisions relating to the legal arrangement of regional cooperation in the management of biological natural resources in the exclusive economic zone. As normative legal research, several approaches are used, namely: statute approach (statute approach); and the conceptual approach [13], using deductive reasoning to gain objective truth. The legal materials used in the research of normative law are: primary law material, secondary law material, and tertiary legal material [14]. The discussion of each of these legal materials, namely:

- Primary legal materials, such as: the provisions of the 1982 Sea Law Convention and the provisions of ASEAN regional cooperation

- Secondary legal materials, in the form of books, journals and research results of legal experts.

- Tertiary legal material, may be dictionaries, such as Indonesian-English dictionary; Black Law Dictionary.

Furthermore, data collection was done through inventory, classification, recording; and systematization of all legal materials, both primary legal materials, secondary legal materials, and tertiary legal materials used in accordance with the issues discussed. Data were analyzed by qualitative descriptive method, including analysis by describing condition or position of legal proposition. Through the processing and analysis of law, conclusions are drawn.

\section{RESUlT AND DISCUSSION}

\section{A. International Standpoint of Cooperation in Natural Resources Management}

International cooperation in the development of agriculture, including natural resources has become one of the successful examples of cooperation and has achieved significant impacts on the livelihoods of the global community. Co-ordinated by the Consultative Group on International Agricultural Research (CGIAR), this collaboration includes 15 centers of international excellence conducting research on crops, fish, water, livestock, forestry, and agroforestry and food policy in collaboration with national agricultural research organizations. [15]. 
In addition to international cooperation efforts, several regional programs have been developed, in particular, In Indonesia. Cooperation at the regional and river level is generally more active and implementation-oriented. Crossborder management is one form of regional cooperation that has developed over the last five decades with international organizations operating in Latin America, Asia and subSaharan Africa. Finally, progress has been made to address the lack of data and knowledge sharing on land and water until it is propagated and adopted by other countries [16].

At the same time, multinational companies have become important actors in land and water. While multinational companies are an important source of technology transfer and foreign exchange earnings for developing countries, developing country legal systems are often unsuitable to protect national interests when there is a conflict over rights and responsibilities over land and water resources. Given the limited scope of this paper, the focus is on the core process of international cooperation pioneered by the United Nations system.

In addition, many multinational companies have also taken part as crucial actors in land and water management. In fact, companies of multinational are an important source of technology transfer and foreign exchange earnings for developing countries, developing country legal systems are often unsuitable to protect national interests when there is a conflict over rights and responsibilities over land and water resources. Given the limited scope of this paper, the focus is on the core process of international cooperation pioneered by the United Nations system.

\section{B. Settlement of Law on Regional Cooperation in Biological Natural Resources Management}

Several inconsistencies and even contradictory provisions have been found. There are instances where sector laws such as the Fisheries Act, Mining Law and are contrary to the Law of Conservation Autonomy Law No. 5 of 1990. There are many provisions of the Conservation Act undermine the inevitable. Unfortunately, there are also some implementing regulations under the Conservation Act in the form of Government Regulation (PP) and the Ministerial Decree has not yet been established. In the absence of these implementing regulations many provisions of conservation laws are not effectively operational.

Along with the rapid development of science and technology, the development of the world today shows the greater the human need for natural resources. Meanwhile, the source of natural resources found in the mainland decreases so that the natural resources of the sea can be an alternative for the fulfillment of the needs of natural resources for the benefit and welfare of mankind in the world. Can utilization of natural resources at sea cause the role of international maritime law becomes important [17]. Especially for Indonesia which has an area of sea (water) is greater than the land area of 9: 1 [18].

Considering the history of conservation activities in Indonesia seems to have started long ago, even before Indonesia was in Dutch occupation. Indonesian society has been handed down wisely utilizing the surrounding natural resources. There is a lot of evidence in the community about the sustainable use of these natural resources, such as the presence of a commander of the sea in Aceh, the ban on Sumatra, the Kelong in Batam, mane, e in North Sumatra, Sasi in Maluku and Papua, awig-awig in Lombok.

The environment's ability to support the livelihood of all living things that includes the availability of natural resources to meet basic needs and the availability of sufficient space to live at a certain level of social stability is called environmental carrying capacity [19].

The existence of natural resources on earth is not spread evenly so that the carrying capacity of the environment in each region will be different. Therefore, its utilization should be maintained in order to continue sustainable and exploitation measures should be avoided.

The efforts of the international community to regulate maritime affairs have succeeded in realizing "United Nations Convention on the Law of the Sea 1982", through the 3rd Sea Law Conference at Jamaica Bay. This Convention has been in effect since 16 November 1994 [20]. This means that the implementation of the provisions contained in the Convention becomes an important matter to be implemented by participating countries, including Indonesia which has ratified the convention through Law Number 17 Year 1985 so that Indonesia is bound by the contents of the Convention.

One important and new part of the international maritime law is the provision on the Exclusive Economic Zone (ZEE). [21] In the ZEE regulatory conventions contained in Chapter V Articles 55 to 75. In essence the provisions on ZEE consist of: (1) Rights and obligations of coastal states; (2) Rights and obligations of other countries; and (3) Provisions in the Convention to regulate all activities in ZEE not included in the rights and obligations of coastal states or other countries [22].

The Exclusive Economic Zone (ZEE) is a sea lane located outside and adjacent to the territorial sea of a coastal state, which is 200 nautical miles measured from the base lines used to measure the width of the territorial sea [23].

Given Indonesia's geographical location in Southeast Asia, the regional cooperation of the ASEAN countries (Association of Southeast Asian Nation) is one of the alternatives to manage fisheries in the Exclusive Economic Zone to utilize the natural resources of fisheries optimally [24].

This regional cooperation by the Indonesian, Malaysian, Singaporean, Muangthai, Philippine, Brunei, and Vietnamese countries incorporated in ASEAN is based on the ASEAN Ministerial Understanding on Fisheries Cooperation, signed on 22 October 1983 [25].

This Agreement serves as the basis for regional cooperation, as it emphasizes regional cooperation in the management and conservation of fisheries resources in ZEE. In addition, efforts to optimally utilize fisheries in Indonesian waters have also been conducted through the Indo Pacific Fishery Council, the South China Sea Fishery Council and the ASEAN Permanent Committee on Food and Agriculture [26]. 
This regional cooperation is intended for fisheries resources in Indonesian waters can be utilized to be able to provide added value for the interests of the nation and the state of Indonesia.

The form of regional and international cooperation in the management of biological natural resources is recognized as significant for the State which performs natural resources management based on accurate data in practice in the community.

However, even though the custom of environmental maintenance is still running well in the community fishermen, but the results of research in the field indicate that has occurred damage in various coastal areas. Damage caused by looting conducted by foreign ships using far more technology superior to local fishermen. On the other hand, the development of ways of arrest fish as opposed to custom and damaging the environment are also done by local fishermen, as was done by the deep West Banker of Kuala Bubon Aceh fishing using trawling [27].

Increased looting of seafood by foreign fishermen and fishing methods which is destructive of the environment, closely related to the weakening of customary control over the region and the lack of ruling support (law enforcement officials), the limited resources of fishermen and fifth laot to overcome that activity destructive is another matter which until now has not been solved. In contrast, in the customary area of laot, the commander of laot and its fishermen have adequate resources, the fight against tiger trawl continues. Pas this becomes possible when fishermen have a strong fleet and better welfare.

Meanwhile, there is also a fishing community that is finally cannot do much when dealing with destructive activities the environment in their territorial waters. Although the commander of laot and fisherman has seeks to prevent bombing and anesthesia activities in the region, but due to the lack of support from law enforcement, their efforts become useless.

\section{CONCLUSION}

Based on the description of the chapters above, it can be made a conclusion to the problems that are made namely:

Legal arrangements for regional cooperation in the management of biological natural resources in the Exclusive Economic Zone include: 1982 Sea Law Convention, Article 56 paragraph (2) on the obligation of coastal states to establish capacity in utilizing fisheries resources in the Exclusive Economic Zone; Article 63 on the obligations of coastal States to undertake regional cooperation in the management and conservation of cross-border fish species; Article 64 concerning the obligations of coastal states to cooperate in the management and conservation of fish species that migrate far; Article 67 paragraph (3) on catadromous species; Article 69 on the rights of non-coastal countries;

Article 70 paragraph (3) of geographically disadvantaged state rights; and Article 123 concerning the cooperation of countries adjacent to closed or semi-closed seas. Besides, we can also find the arrangement through ASEAN Ministerial Understanding on Fisheries Cooperation Year 1983.

\section{ACKNOWLEDGEMENT}

The author would like to thank all the parties who have helped and contributed in the writing of this article, both those who contribute in the form of funding and critical ideas. Hopefully this paper can be useful theoretically and practically for the addition and development of knowledge, especially in the field of legal science.

\section{REFERENCES}

[1] R. Febriamansyah, Yonariza, R. U. Shivakoti, and Ganesh P., "Redefining Diversity and Dynamics of Natural Resources Management in Asia: The Reciprocal Relationship between Governance of Natural Resources and Socio-Ecological Systems Dynamics in West Sumatra Indonesia." Elvisier 4: 244. 2017.

[2] Sovacool, B. K., "Environmental Science \& Policy Countering a Corrupt Oil Boom : Energy Justice, Natural Resource Funds ,' E Pr1 ' Ncipe 'S Oil Revenue Management Law O Tome and Sa." Environmental Science and Policy 55: 196-207. 2016.

[3] M. Umi, "Review of National Laws and Regulation in Indonesia in Relation to an Ecosystem Approach to Fi Sheries Management." Marine Policy 91 (August 2017): 150-60. 2018.

[4] F. Carl, "Resilience: The Emergence of a Perspective for SocialEcological Systems Analyses." Global Environmental Change 16(3): 253-67. 2006.

[5] Clark, W. C., "Sustainability Science: A Room of Its Own." Proceedings of the National Academy of Sciences 104(6): 1737-38. 2007.

[6] Bettencourt, L. M. A., and J. Kaur, "Evolution and Structure of Sustainability Science." Proceedings of the National Academy of Sciences 108(49): 19540-45. 2011.

[7] Hukum, Memberikan Kepastian, Hak Usaha, and Pemanfaatan Sumberdaya Hutan. "Kajian Kebijakan Konservasi Sumber Daya Alam Hayati Dan Ekosistemnya." 2010.

[8] B. Suvi, "Forest Policy and Economics Reviewing Natural Resources Law in the Light of Bioeconomy: Finnish Forest Regulations as a Case Study." Forest Policy and Economics 88(August 2017): 11-23. 2018.

[9] Cerceau, Juliette, N. Mat, and G. Junqua, "Geoforum Territorial Embeddedness of Natural Resource Management: A Perspective through the Implementation of Industrial Ecology." Geoforum 89(December 2017): 29-42. 2018.

[10] D. M. Johnston, International Symposium on the Law of the Sea in Southeast Asia, Dalhousie Ocean Studies Program, Halifax. 1983.

[11] Barrow M., Natural Resources, 2010.

[12] R. H. Soemitro, Metodologi Penelitian Hukum, Penerbit Ghalia Indonesia, Jakarta. 1983.

[13] P. M. Marzuki, Penelitian Hukum, Penerbit Kencana, Jakarta, 2006.

[14] S. Hartono, Penelitian Hukum Di Indonesia pada Akhir Abad Ke-20, Penerbit Alumni Bandung. 1994.

[15] Nkonya, E., N. Cenacchi, C. Ringler, and D. Lantieri. "International Cooperation for Sustainable Land and Water Management." : 1-44. 2011.

[16] Roberts, A. M., "The Role of Transboundary Natural Resource Management In Peace Building Across International Borders.” 2002.

[17] M. Kusumaatmadja, Perlindungan dan Pelestarian Lingkungan Laut Dilihat dari Sudut Hukum Internasional, Regional, dan Global, Sinar Grafika dan Pusat Studi Wawasan Nusantara Bandung. 1992.

[18] S. L. Putu, Pengelolaan Pencemaran Laut Di Indonesia, Cetakan Ke-3, PenerbitR.A. De. Rozarie, Surabaya, 2015. 
[19] Biologi: Sumber Daya Alam (http://bebas.ui.ac.id/v12/sponsor/ Pendamping/Praweda/Biologi/0040\%20Bio\%.htm) 2009 diakses pada 6 Agustus 2011.

[20] Commentary, Nordquist, United Nations Convention on the Law of The Sea 19822, Vol. I, Martinus Nijhoff Publishers, Boston. 1985.

[21] C. Anwar, Zone Ekonomi Eksklusif Di dalam Hukum Internasional, Sinar Grafika, Jakarta. 1995.

[22] B. Kwiatkowska, The Exclusive Economic Zone in The New Law of the Sea, Martinus Nijhoff Publishers, Dordrecht. 1989.

[23] D. J. Attard, The Exclusive Economic Zone In International Law, Clarendon Press, Oxford. 1987.

[24] Annual Report of the ASEAN Standing Committee 1989 - 1990, ASEAN Secretariat, 1990, Jakarta.

[25] ASEAN Basic Document, Fakultas Hukum UNPAD, Bandung. 1993.

[26] ASEAN Document Series 1991 - 1992, ASEAN Secretariat, 1992, Jakarta.

[27] Anonimous, "Dokumen Analisis Kebijakan Pengelolaan Sumber Daya Kelautan Dan Perikanan Provinsi Nanggroe Aceh Darussalam" 58. 2007. 